\title{
TaTME y anastomosis coloanal con técnica de pull-through para tratamiento del cáncer de recto inferior
}

\author{
Nicolás Avellaneda ${ }^{1,2}$, Augusto Carrie ${ }^{1,2}$, Juan Pablo Muñoz ${ }^{2}$
}

${ }^{1}$ Departamento de Cirugía General, Centro de Educación Médica e Investigaciones Clínicas “Norberto Quirno” (CEMIC). Ciudad Autónoma de Buenos Aires, Argentina.

${ }^{2}$ Nueva Proctología. Ciudad Autónoma de Buenos Aires, Argentina.

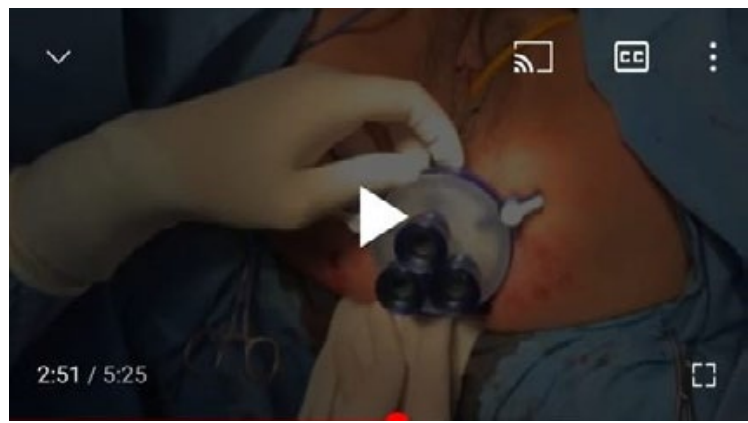

\section{RESUMEN}

El tratamiento quirúrgico del cáncer de recto inferior representa un desafío para el equipo tratante, ya que conlleva la necesidad de realizar un procedimiento oncológicamente seguro, con una morbilidad significativa y una potencial alteración de la continencia postoperatoria que puede alterar la calidad de vida de los pacientes. Por todo esto, se han descripto varias técnicas para realizar la anastomosis coloanal.

Se presenta el caso de una mujer de 52 años de edad que es derivada a la consulta de cirugía colorrectal por presentar un tumor a nivel de recto inferior. Se solicitan estudios de estadificación, resultando ser un rmT4bN0 con EMVI y margen de resección circunferencial positivos, con invasión del músculo elevador del ano. No presenta enfermedad a distancia. Se realiza tratamiento neoadyuvante y 9 semanas después de completar dicho tratamiento, siendo ahora un rmT1sm3N0, sin invasión del músculo elevador del ano, con EMVI y margen de resección circunferencial negativos.

Se decide tomar conducta quirúrgica. Se aborda la cavidad abdominal por vía laparoscópica y luego de una exploración en búsqueda de lesiones inadvertidas en estudios previos, se aborda la vena mesentérica inferior por vía medial, descendiendo el ángulo esplénico. Posteriormente se realiza una ligadura alta de los vasos mesentéricos inferiores. Luego de finalizado el tiempo abdominal, que continúa hasta la reflexión peritoneal, se lleva a cabo la escisión total del mesorrecto por vía transanal, comenzando por una disección interesfintérica y debiendo seccionar parcialmente el esfínter anal interno. Una vez unidos ambos abordajes, superior e inferior, se realiza una anastomosis tipo pull-through. Elegimos esta técnica porque resulta menos costosa (no requiere sutura mecánica), disminuye el índice de fístula anastomótica (complicación más frecuente dado que la pelvis presenta antecedente de tratamiento radiante), no requiere ileostomía de protección (la demora en el cierre de la misma puede aumentar la incidencia de síndrome de resección anterior) y presenta buenos resultados funcionales.

La anastomosis se realiza siguiendo los principios descriptos por Turnbull-Cutait con algunas modificaciones: no realizamos mucosectomía y tampoco realizamos puntos cardinales para fijar el ostoma. El mismo se secciona a los 15 días del postoperatorio (procedimiento ambulatorio, la paciente ya externada).

La anatomía patológica informó un adenocarcinoma de recto inferior con bajo grado histológico, fascia mesorrectal intacta, con ganglios negativos (estadio T1N0Mx).

Tres meses después de la cirugía, la paciente presenta adecuada contracción voluntaria y adecuada continencia.

Palabras claves: Cáncer; Recto; TaTME; Pull-through; Anastomosis; Coloanal

\section{ABSTRACT}

The surgical treatment of low rectal cancer represents a challenge for the treating team, who need to perform an oncologically safe procedure that entails a significant morbidity and a potential alteration of the postoperative continence that can alter the quality of life of patients. For all this, several techniques have been described to perform the coloanal anastomosis.

The case of a 52-year-old woman referred to colorectal surgery consultation for a tumor in the lower rectum is presented. Staging studies revealed a rmT4bNO tumor, with invasion of the levator ani muscle, positive EMVI and positive circumferential resection margin. No distant disease. She underwent neoadjuvant treatment and 9 weeks after completion a new MRI showed rmT1sm3N0 tumor, without invasion of the levator ani muscle, negative EMVI and negative circumferential resection margin.

Surgical treatment was decided. The abdominal cavity was approached laparoscopically and after an abdominal exploration to rule out undiagnosed lesions, the inferior mesenteric vein was approached medially, and the splenic flexure taken down.

\author{
Nicolás Avellaneda \\ n.avellaneda86@gmail.com \\ Recibido: julio de 2020. Aceptado: agosto de 2020
}

Los autores declaran no tener ningún conflicto de interés. 
Subsequently, a high ligation of the inferior mesenteric vessels was performed. After the end of the abdominal dissection which continues up to the peritoneal reflection, total excision of the mesorectum is carried out transanally, starting with an intersphincteric dissection, with and partial section of the internal anal sphincter.

Once both upper and lower approaches are joined, a pull-through anastomosis is performed. We chose this technique because it is less expensive (it does not require stapled instruments), reduces the rate of anastomotic fistula (more frequent in cases of radiated pelvis), does not require protective ileostomy (the delay in its closure can increase the incidence of anterior resection syndrome) and presents good functional results.

The anastomosis is performed following the principles described by Turnbull-Cutait with some modifications: we do not perform mucosectomy, or cardinal fixing stitches. The transanal exteriorized colon is sectioned 15 days after surgery (as an outpatient procedure).

The histopathology reported an adenocarcinoma of the lower rectum with low histological grade, intact mesorectal fascia and negative nodes (T1NOMx).

Three months after surgery the patient presents adequate voluntary contraction and adequate continence.

Keywords: Cancer; Rectum; TaTME; Pull-through; Anastomosis; Coloanal

\section{COMENTARIO}

Interesante presentación en formato video de resección total de mesorrecto con abordaje laparoscópico y transanal con disección interesfinteriana para el tratamiento de cáncer de recto bajo postneoadyuvancia, con el agregado distintivo de la utilización de la técnica pull-through para la anastomosis. La calidad de las imágenes es superlativa para esta técnica que requiere gran destreza en laparoscopía.

Tal como lo describen, la técnica pull-through tiene como potencial ventaja una baja tasa de ostomía definitiva. Sin embargo, en un ensayo clínico randomizado multicéntrico del corriente año, no se pudo demostrar la superioridad de esta técnica sobre la anastomosis coloanal manual con ostomía de protección respecto a complicaciones a corto plazo ni tampoco en los resultados oncológicos y funcionales al año. ${ }^{1}$

En nuestro equipo quirúrgico, independientemente de la técnica anastomótica a utilizar, preferimos no extraer el recto a través del ano debido a la posibilidad de dañar el mesorrecto, ya que las piezas quirúrgicas suelen alcanzar gran tamaño. Esto podría traer como desventajas impedir un estudio anatomopatológico óptimo y el riesgo de eventual implante tumoral. Desventaja que, en este caso, los autores pudieron sortear.

Joaquin Tognelli

Sanatorio Sagrado Corazón y Sanatorio Finochietto, Ciudad Autónoma de Buenos Aires, Argentina.

\section{REFERENCIAS}

1. Biondo S, Trenti L, Espin E, Bianco F, Barrios O, Falato A, De Franciscis S, Solis A, Kreisler E; TURNBULL-BCN Study Group. TwoStage Turnbull-Cutait Pull-Through Coloanal Anastomosis for Low Rectal Cancer: A Randomized Clinical Trial. JAMA Surg. 2020 Jun 3;155(8):e201625. doi: 10.1001/jamasurg.2020.1625. Epub ahead of print. PMID: 32492131; PMCID: PMC7270870. 